\title{
Divisions of Labor: The Splintered Geography of Labor Markets and Movements in Industrializing America, 1790-1930
}

\section{CARVILLE EARLE}

Among the various methodological prescriptions of Anthony Giddens, perhaps the most useful for labor history are his advisories on social change, on the anxieties and tensions attending a society's transition from one geographical scale to another. ${ }^{3}$ Labor's experience in the United States offers a case in point. The nation's transformation from a preindustrial to an industrial society entailed, in addition to the inexorables of accelerated urbanization, industrial expansion, and market extension, certain fundamental changes in the conditions of labor. Industrialization restructured the geography of labor markets, revised principles of wage determination, fomented sectarian division in the ranks of labor, and soured the relations between labor and capital. These structural changes led, in turn, to the inevitable responses of, among others, worker combination, protest, industrial violence, and a splintering in the ranks of labor.

Although the contours of these momentous social changes are well known, thanks to the diligence of labor historians, we know next to nothing about their geographical particulars, about the evolving geography of labor and labor markets. ${ }^{2}$ And for good reason since the methodological directives of American labor history have privileged one or another of two scalar extremes. These directives fasten inquiry either on microscale case studies of community and locale or on macroscale studies of national institutions - the axis, not coincidentally, of older and newer approaches to institutional and social labour history, respectively. ${ }^{3}$ Only on rare occa-

Any synthesis of the sort attempted here does a disservice to the literatures on which it depends for the simple reason that space precludes comprehensive citation. I trust, therefore, that my abridged set of references offers a hint of the richness of this literature and of my rather sizable debt to historians, sociologists, economists, and geographers, cited and not.

1 Anthony Giddens, "Structuration Theory: Past, Present and Future", in Christopher G.A. Bryant and David Jary (eds.), Giddens' Theory of Structuration: A Critical Appreciation (London, 1991) pp. 201-221.

2 Among others, Herbert Gutman, Work, Culture and Society in Industrializing America (New York, 1976); David Montgomery, Workers' Control in America: Studies in the History of Work, Technology, and Labor Struggles (Cambridge, 1979); and John R. Commons, History of Labor in the United States (4 vols.; New York, 1935).

3 David Brody, "The Old Labor History and the New: In Search of an American Working Class", Labor History 20 (1979), pp. 111-126. On scales of analysis, various essays in Jeffrey C. Alexander, ef al. (eds.), The Micro-Macro Link (Berkeley, 1987); Charles Tilly, Big Siructures, Large Processes, Huge Comparisons (New York, 1984).

Intemational Review of Social History 38 (1993), pp. 5-37 
sions do these inquiries abandon scalar extremism and attend to the richly textured middle ground (mesoscale) of an as yet unwritten historical geography of American labor.

This methodological preoccupation with the very small or the very large is especially ironic for students of social change since, as Giddens reminds us, most great transitions, and certainly the transition from preindustrial to industrial worlds, run directly through the middling scales of metropolis and region. Yet save for the pioneering efforts of Shorter and Tilly, Hobsbawm and Rude, and a few others, students of labor history seem disinterested in this coaxial zone of mediation and translation. ${ }^{4}$ Eschewing mesoscale mappings of wages, worker protests, unionization, labor force, and the like has its consequences, however. And not the least of these is the obliteration of spatial context and subtext when inquiries are conducted, respectively, at micro (community) and macroscales (national institutions) of analysis.

Consider the microscale methodology of labor history. Community case studies, however insightful on matters of strategy, constraint, and action, rarely address their aptitude for inquiry. Is the case representative of all places and times, or of certain classes of places in time? Or is it a revealing anomaly? These are questions simultaneously of context and conditionalization - of positioning a case in periodic time and regional space, of typicality. ${ }^{3}$ Herbert Gutman, the late dean of American labor history, forthrightly addressed these issues in proposing the hypothesis of an inverse relation between a community's level of modernity and its propensity for worker protest. His strategy provided at once argument - the declension of labor power in the course of modernization - and context - a specification of discrete microscale communities in their systematic mesocale geography. ${ }^{6}$

At the opposite extreme, consider the surreality of macroscale interpretations of labor history, divorced as they are from spatial and temporal particulars. In cobbling together coarsely drawn state and national statistics, institutional trends detached from the places that shaped them, and anecdotal data from highly varied places and times, these interpretations obscure systematic (regional) and particular (local) variances in strategy, constraint, and action. The problem with treating macroprocesses in this fashion is that it overlooks the spatially recursive nature of social change; to be sure, macroscale processes shape events at local and regional scales,

\footnotetext{
4 Edward Shorter and Charies Tilly, Strikes in France, 1830-1968 (New York, 1974); E.J. Hobsbawn and George Rude, Captain Swing: A Social History of the Great English Agricultural Uprising of 1830 (New York, 1968); and Herbert Gutman, "The Workers' Search for Power: Labor in the Gilded Age", in H. Wayne Morgan (ed.), The Gilded Age: A Reappraisal (Syracuse, N.Y., 1963), pp. 38-68.

"Carville Earle and Leonard Hochberg, "Varieties of Gcohistorical Social Science", in Geographical Perspectives on Social Change (Stanford, forthcoming).

'Gutman, "The Workers' Search for Power", pp. 38-68.
} 
but they are also shaped by these events. ${ }^{7}$ The origins of the American Federation of Labor in the 1880 s offers a telling case in point. The beginnings of this most important macroscale trade-union organization simply , cannot be understood independently of mesoscale responses to the general strike of 1 May 1886 and the Haymarket "Riot" three days hence. ${ }^{8}$

Recall the scene as a handful of trade unionists in the Federation of Organized Trades and Labor Unions (FOTLU) formulated plans for and carried through with a general strike of all workers on behalf of the eighthour day. The strike's geography taught several mesoscale lessons for macroscale trade-unionist strategy. Not the least of these was the location of loyal trade-unionist constituencies in the large industrial cities in the northeastern quadrant of the nation. In short order thereafter, FOTLU's overtures to the Knights of Labor ceased, and visions of a unified working class were abandoned. Trade unionists embraced instead their loyalist urban constituency and (for other spatial reasons soon revealed) embarked on a parochial and decentralized policy of "pure and simple" trade unionism - a policy formally ratified with the founding of the AFL in December 1886 , less than nine months after the general strike. Ironically, labor history has paid little heed to the role of the general strike in enabling this momentous shift in the ranks of labor. That oversight, I submit, has a great deal to do with a methodology in extremis, a methodology which privileges micro and macroscales of inquiry. In the case of the general strike, however, the one is too particular and the other too general for rehearsal of the mesoscale spatial lessons which decisively deepened the schism in the ranks of American labor.

The dilemma of labor historiography, therefore, is that it sees the forest and the trees, while missing most everything in between. And it is this space in between - at the mesoscale of metropolis and region - which constitutes the peculiar domain in geography. And as it turns out, these mesoscale spaces also constitute the translational domain of social change, where national (macroscale) strategies intersect with microscale (local) actions, where structure and agency meet, and where individuals in locales creatively maneuver amidst a field of structural constraints. Which is to say that labor's actions in place are problematic; they cannot be deduced from the macroscale structures that bind them; nor generalized from unconditionalized case studies at the microscale.

' Giddens, "Structuration Theory", pp. 20-21; Allan Pred, Place, Practice and Structure: Social and Spatial Transformation in Southern Sweden, 1750-1850 (Totowa, 1986), pp. 5-31; Derek Gregory, "Contours of Crisis? Sketches for a Geography of Class Struggle in the Early Industrial Revolution in England", in A.R.H. Baker and D. Gregory (eds.), Explorations in Historical Geography: Interpretative Essays (Cambridge, 1984), pp. 68-117.

-The spatial lessons of the general strike are examined in some detail later in the essay; citations are reserved to that discussion.

- On the limits of cross-scalar inference, see Gillian Rose, "Locality Studies and Waged Labour: An Historical Critique", Transactions of the Institute of British Geographers, N.S. 14 (1989), pp. 317-328. 
All is not contingency, however, in societal-cum-scalar transitions. Modernization and industrialization, for example, are not purely chaotic and disruptive processes; their advance, on the contrary, hinges on institutions which abstract and distance social relationships and thereby facilitate transitions to the mesoscale. Of the various institutions available, the market is the most obvious and perhaps the most powerful. The market is, above all, a spatial abstraction, a means for mediating the exchange of goods and services (an invisible hand, as it were) among producers and consumers unknown to one another and disjunct in space. This process of spatial abstraction, what Giddens' calls distanciation, traces its origins to Western European capitalism and the sixteenth-century ascendance of the market, or more precisely, a triad of markers - for products, for capital, and for labor. ${ }^{10}$ For reasons which remain unclear, the market for labor evolved more slowly than the others. Not until the nineteenth century did the pace quicken, but once underway labor markets advance swiftly through three stages of a half century more or less. A word on each is in order.

In the first of these three stages, lasting perhaps from the sixteenth to the early nineteenth centuries, rural economy sets the tone. Agrarian hegemony translates into labor markets which are dual and asymmetric. Rural labor markets are large and powerful; urban ones are small and weak. In these asymmetric markets, wages of unskilled urban workers are determined, more or less, by rural earnings and the transfer wage. The latter equals the wage which is required to induce rural workers into unskilled urban employment, and its level is defined by opportunities in the vastly larger rural labour market and by the incomes workers could earn therein. These earnings, in turn, are established by the seasonal demands for labor of the staple crops produced within the encompassing agrarian region. Put succinctly, the transfer wage varies inversely with the seasonality of labor demand in the regional agrarian system, that is, wages are low in agrarian regimes which are highly seasonal, and high in regimes reliant on labor the year round. When a low transfer wage prevails, the ranks of labor are often riven as skilled labor fears displacement by cheap, unskilled workers and machine production; when the transfer wage is high, these fears are allayed and skilled workers make common cause with their well-paid but unskilled brethren. ${ }^{11}$

${ }^{10}$ Giddens, "Structuation Theory", pp. 201-221; idem, The Constitution of Society: Outline of the History of Structuration (Berkeley, 1984); John Urry, "Time and Space in Giddens" Social Theory", in Giddens' Theory of Structuration, pp. 160-175. On markets and the rise of capitalism, Katl Polanyi, The Great Transformation: The Political and Economic Origins of Our Time (Boston, 1957), pp. 163-219; Douglass C. North and Robert P. Thomas, The Rise of the Western World: A New Economic History (Cambridge, 1973).

"On early-modern markets and their contemporary analogues, Carville Earle, Geographical Inquiry and American Historical Problems (Stanford, 1992), pp. 173-235; Stanley Lebergott, Manpower in Economic Growth: The American Record Since 1800 (New York, 1964); W. Arthus Lewis, "Reflections on Unlimited Labour", in Luis Eugenio DiMarco (ed.), International Economics and Development: Essays in Honor of Raull Prebisch (New York, 1972), 
As industrialization advances, labor-market evolution enters its second stage. This stage is characterized by the emergence of autonomous and crudely segmented urban labor markets. It begins in large urban and industrial centers, where labor markets secure their independence from the rural economy. Having achieved autonomy, these markets subdivide into two distinct classes - the first, a highly competitive market for unskilled labor employable in a wide variety of urban industries; the second, an imperfectly competitive market for skilled workers whose specialized skills bind them to one (monopsony) or at most a few (oligopsony) firms. In the former, wages are determined eventually by marginalist economic principles; in the latter, by exercises of raw power pitting "combinations" of skilled workers against the relevant firm or firms. These radically divergent strategies of compliance and resistance, in turn, reinforce the schismatics inherent in urban labor markets in this, unskilled labor's "golden age". ${ }^{12}$

Industralization's triumphant dominance of the economy signals the third stage in labor-market evolution. In this stage, the debate over market perfection or imperfection is joined. Skilled workers continue their struggle to eliminate market imperfections (monopsony and oligopsony) through the collective actions of "combination" and protest. Entrepreneurs, meanwhile, seek to extend these imperfections into industries with large through-put. This they do by balkanizing the labor market, by parsing the task of unskilled and skilled labor into an infinitely expansible hierarchy of semiskilled, firm-specific jobs. In accordance with the latest principles of scientific management, their aims were nothing less than the transformation of the workplace, the imperfection of unskilled labor markets, and an end to unskilled labor's "golden age". That their actions inspired resistance among unskilled workers - a resistance modeled on the venerable repertoire of strategies and tactics previously developed by skilled workers - is testimony to the scope and power of managerial invasion into the American industrial system. ${ }^{13}$

Note, contra Giddens, that the historical process of labor-market evolution involves a narrowing of the spatial extent of labor markets. The abstraction of the market is progressively particularized (instantiated) to

pp. 75-96. And more generally, Friedrich Lenger, "Beyond Exceptionalism: Notes on the Artisanal Phase of the Labour Movement in France, England, Germany, and The United States", International Review of Social History 36 (1991), pp. 1-23.

12 Of the several stages of labor-market evolution, the second is the least well known. This story of unskilled labor's golden age therefore is pieced together from a variety of sources later cited in full.

"I am prepared to argue that labor markets were transformed by the advent of new managerial practices in response to large-scale industrial production; that does not imply assent, however, to a model of societal transition from industrial to monopoly capitalism. See Richard Edwards, Contested Terrain: The Transformation of the Workplace in the Twentieth Century (New York, 1979); David F. Noble, America by Design: Science, Tecinology, and the Rise of Corporate Capitalism (New York, 1977). 
highly specific places, firms and tasks - first in agrarian regions, next in autonomous and insular urban labor markets, and last in particular tasks in a particular place in a particular firm. And it is these spatial transitions from meso to microscales which constitute the changing field of action and reaction for workers as well as for industrial entrepreneurs and managers. ${ }^{14}$

The historical geography of American labor nicely illustrates these several stages in labor-market evolution during the course of economic development, 1790-1930. These mesoscale transformations would unfold in the nation's northeastern quadrant - in what was to become known as the "American Manufacturing Belt" - over three periods of a half century more or less. For ease of exposition, these periods or stages divide as follows:

(1) $1790 \mathrm{~s}-1830 \mathrm{~s}$ - frontier expansion and industrial revolution: rural hegemony over asymmetric labor markets;

(2) 1840 s-1890s - frontier closure and economic involution; the emergence of autonomous urban labor markets, more or less perfect;

(3) $1890 \mathrm{~s}-1930 \mathrm{~s}$ - preindustrial and industrial worlds: radical labor politics, scientific management, and the imperfecting of labor markets.

These several stages constitute a scaffolding for the geography of American labor history. Indeed, the stages are themselves constructed about a set of geographic processes which define mesoscale fields of action - that changing constellation of places, small and large, in an expansive industrializing nation - as well as the abstract means (the changing structure of labor markets) for articulating, however imperfectly, demand and supply. In all this there is a double irony. The first of these is that labor-market evolution has more to do with market constriction than with market dilation; more to do, in other words, with instantiated abstractions than with Giddensian mechanisms of distanciation. The second irony, which follows from the first, is that the search for perfection in labor markets was led by workers and not by entrepreneurs (or neoclassical economists). Towards that end, American workers engaged in a series of heroic struggles; these were countered, however, by entrepreneurial adversaries who adroitly deployed various mechanisms of market imperfection. Labor exploitation, as a consequence, endures as an uncomfortable fact for capitalism's apologists who would have us believe in (even as their actions discredit) the wonder-working powers of marginalism and perfectly competitive markets.

\section{Frontier expansion and industrial revolution: the rural hegemony over asymmetric labor markets}

No period of similar length in American history compares with the momentous changes which took place between 1790 and 1840. In that half

14 These imperfections in product and labor markets are standard fare in neoclassical microeconomies and are discussed in most texts introducing that field. 
century, population exploded outward toward the frontier at an annual rate of 2.5 percent, towns grew into cities in what seemed an instant of time, and the northeastern states embarked on an industrial revolution which would transform the nation. One wonders, however, if all of this dynamism might have melted into thin air had it not pivoted around a vast and productive rural economy. That economy, or more precisely series of economies, imposed its hegemony on the society as a whole. Its sheer size defined the parameters of urban labor markets everywhere but most especially in the nascent urban centers aborning in the northeastern states. These rural parameters at once regulated the level of urban wages and fixed them at levels which, in the case of the northern states, favored industrialization and urban growth. We begin, accordingly, with the industrial revolution and the asymmetric labor markets which facilitated, even permitted, this transformation. ${ }^{15}$

The American industrial revolution was probably premature. To be sure Alexander Hamilton and other Federalists did all in their power to stimulate infant industries, but the rise of factory production probably owed as much to a happy conjuncture of demand - the benevolent protection afforded by international warfare and an age of revolution - and supply a dependable supply of cheap labor and the machines for them to use as to explicit policy measures such as bounties, tariffs, and the like. Consider first the timing of the revolution. The "protectionism" afforded by three and a half decades of international warfare was a Federalist's dream come true. Napoleon's campaigns disrupted oceanic trade and sheltered infant industries in the United States as well as in England and on the Continent. And when in 1815 Napoleon was at last put to bed and the Anglo-American war came to a close, Americans hastened to replace the industrial protectionism afforded by Atlantic warfare with the controversial tariff of $1816^{16}$

In this context of commercial chaos and economic uncertainty, American industry took root - but not everywhere, of course, for reasons which had more to do with supply than with demand. The geography of the new factories for making coarse cloth, the furnaces for making pig iron and castings, and the iron mills for rolling and slitting was lopsidedly concen-

is George Rogers Taylor, The Transportation Revolution, 1815-1860 (New York, 1951); Douglass C. North, The Economic Growth of the United States, 1790-1860 (Englewood Cliffs, N.J., 1961); Carville Earle and Changyong Cap, "The Rate of Frontier Expansion in American History, 1650-1890", in Geographic Information Systems and the Social Sciences: A Handbook, in Carville Earle, Lconard Hochberg, and David Miller (Basil Blackwell, forthcoming).

${ }^{16}$ On the macrohistorical paradox of protectionism in this period, see Earle, Geographical Inquiry, pp. 455-459. Paul A. David makes the neoclassical case against the benefits of tariff protection, albeit after 1824 when the foundations for industrialization were already in place; in "Learning by Doing and Tariff Protection: A Reconsideration of the Case of the AnteBellum United States Cotton Textile Industry", in Tec/mical Choice Imnovation and Economic Growth: Essays in American and British Experience in the Nincteenth Century' (London, 1975), pp. 95-173. 
trated in the northeast and, more precisely, on the outskirts and in the hinterlands of entrepôts such as Boston, New York, Philadelphia, and Baitimore. These "suburban" and rural locations held several advantages for budding industrial entrepreneurs including, of course, access to water power. To be sure water was important for textile manufacturers, but it was of lesser significance for iron producers and fabricators who refined their product along an extended spatial chain that stretched from the interior forests to the heart of the coastal cities. ${ }^{17}$

But nature's endowment was hardly the decisive factor in northeastern industrialization. More important than natural resources was the availability of a low-cost labor force which could be mobilized for industrial production. And on that front, the northeastern states enjoyed a special advantage. The region, as Hamilton observed in dismissing pessimistic opinions on the nation's industrial prospects, had four sources of inexpensive labor:

(1) children; (2) women; (3) immigrants; (4) seasonally unemployed farm laborers.

By 1840 American manufacturers had mobilized these supplies of unskilled labor - women in New England, women and farm laborers in the Middle States, and children in both. ${ }^{18}$

Mobilization occurred in various ways and combinations. Textile manufacturers, for example, combined cheap, unskilled labor with machines for spinning and weaving in mills on the outskirts of Boston (Waltham), Philadelphia (Manayunk), and Baltimore (Hampden, Ellicott City). The first of these used women and children; the others, women, men, and children. Iron manufacturers in Pennsylvania and Maryland similarly deployed cheap labor - in this case, seasonally unemployed farm laborers who were hired on for the winter tasks of chopping, hauling, and stacking cordwood for the collieries and iron furnaces.

But if Hamilton had successfully identified the sources of cheap American labor, he failed to provide a theoretical explanation for the paradox of cheap labor in the midst of land abundance. In theory, labor should have been dear owing to vast quantities of cheap land and a rapidly expanding frontier. And the absence of cheap labor, as Hamilton's critics averred, should have precluded industrialization.

The debate can be resolved, in Hamilton's favor, by tracing the sources of cheap labor to the workings of mesoscale labor markets in developing economies. Virtually everyone agrees on two points: first, that labor markets in these economies are dual and asymmetric, consisting of a large rural market and a much smaller urban one; second, that unskilled urban wages are determined largely by the annual earnings of rural workers.

${ }^{27}$ Curtis P. Nettles, The Emergence of a National Economy, 1775-1815 (New York, 1962); Diane Lindstrom, Economic Development in the Philadelphia Region, 1810-1850 (New York, 1978).

${ }^{13}$ Samuel McKee, Jr. (ed.), Alexander Hamilton's Papers on Public Credit, Commerce and Finance (New York, 1934), pp. 177-276, esp. pp. 206-208. 
That is, the earnings of rural workers establish a transfer wage sufficient to bid them into unskilled work in the city. Disagreement arises, however, with regard to the level of rural earnings - and thus the transfer wage. Proponents of labor scarcity mistakenly project daily farm wages over a full year; doing so results in vastly inflated earnings, a high transfer wage, and excessively dear urban labor. Proponents of cheap labor, conversely, allow for the seasonality of rural work and they calibrate rural earnings accordingly, that is, multiplying the prevailing daily rural wage by the number of working days required in a crop's season. ${ }^{19}$

And in the wheat and corn belts of the Middle Atlantic states, seasonality was acute. Farmers there customarily hired labor for the "crop season" which lasted from corn planting in April through the harvest of small grains in June and July. Projecting rural earnings for the "season" rather than over the year leads to a dramatic reduction in the bidding level (transfer wage) for unskilled urban workers. Even allowing for supplemental earnings from by-employment in the off-season, rural earnings in these grain belts are a third to a half of the wages estimated by proponents of labor scarcity. In sum, the union of agrarian seasonality and asymmetric labor markets resulted in a low transfer wage which in turn facilitated industrialization based on cheap unskilled labor and machines.

This windfall for urban entrepreneurs disappears, however, as the agrarian season lengthens - as occurred in the American cotton belt and tobacco coast or even in the intensive mixed-farming systems in England. In these cases, where rural labor worked ten to twelve months per year, the cost of bidding them into nearby urban centers nearly doubled those in the grain-belt cities of Baltimore, Philadelphia, and New York. In these cities and their satellites, entrepreneurs housed cheap unskilled labor and machines in factories on the urban periphery, and there laid the foundations for industrial revolution as well as for schism between unskilled workers and the skilled craftsmen whom they threatened to displace. ${ }^{20}$

With minor amendment, the thesis of cheap labor as the basis for American industrialization can be extended from the Middle States to New England. The difference, of course, turns on New England's mobilization of young women for work in the textile mills of Waltham, Lowell, and Providence. A surplus of women seems to have arisen as the countryside was drained of young men who abandoned an unproductive agrarian system for the frontier. Male outmigration to New York and the upper Midwest left behind an imbalanced sex ratio which for many women meant the deferral of marriages for years or even a lifetime. Unable to marry and settle in the countryside, these young women regularly accepted the

${ }^{19}$ On the debate over cheap labor or dear, see Earle, Geographical Inquiry, pp. 173-236, 325-328, and 406-416; David, Technical Choice Innovation, pp. 19-91. For the social and political implieations of wage structure, see the acute observations of David Montgomery, "The Working Classes of the Pre-industrial American City, 1780-1830", Labor History 9 (1968), pp. 3-22.

2o Earle, Geographical Inquiry, pp. 173-236, 315-328, and 406-416. 
blandishments of the textile mills which sprang up in the region. And while most women did not make a life of it, in the time allotted they provided industrial entrepreneurs with an inexpensive source of labor until the closure of the frontier in the 1840 s displaced them with native and immigrant men. ${ }^{21}$

The odd coupling of cheap labor and hell-bent frontier expansion in the period 1790-1840 was not as paradoxical as economists would have us believe. In New England, frontier expansion cheapened the labor of women left behind. And in the middle American grain belt, a productive if seasonal agrarian system retained its males as it cheapened their labor for urban and industrial entrepreneurs. Cheap labor thus enabled an industrial revolution even as the nation extended its frontiers of settlement.

That revolution transformed society and economy in the northeastem states. Urbanization there rose from 8 percent to nearly 19 percent between 1790 and 1840 . The pace was even faster in Massachusetts and Rhode Island, where city folk in 1840 made up 38 percent and 44 percent of the population, respectively. Industrialization and western trade equally stimulated expansion in the region's principal seaports, four of which exceeded 100,000 persons by 1840 , led by New York's 360,000 . And it was these places which were largely responsible for generating some $\$ 240,000,000$ in manufacturing value added in 1839 - an impressive amount (worth roughly one-third of agriculture's contribution) for this youthful sector of the American economy. ${ }^{22}$

The industrial revolution in the northeast was well underway by 1840 , yet it is important to keep these changes in perspective. Few of these new factories were really large. Probably no more than ten of them employed 100 workers or more; indeed, Baltimore and Boston had none. Moreover, the region and the nation remained predominantly rural and agricultural. Although American manufacturers made a sizable contribution to the American economy, that total paled in comparison to the increments provided by agriculture, commodity trade and transport, and the service sector. ${ }^{23}$ And given the vast size of the rural economy, labor markets in the emerging cities and towns remained dependent on conditions in the

${ }^{21}$ Montgomery. "The Working Classes". pp. 3-22; Historical Statistics of the United States from Colonial Times to 1970, Part 1 (2 parts; Washington, 1975), pp. 24-37; U.S. State Department, Digest of Accounts of Manufacturing Establishments in the United States, and of Their Manufacture (Washington, 1823); Zachariah Allen, The Science of Mechanics (Providence, R.L., 1829), p. 347; Alexander J. Field, "Sectoral Shift in Antebellum Massachusetts: A Reconsideration", Explorations in Economic History 15 (1978), pp. 146-171; Thomas Dublin, Women at Work: The Transformation of Work and Community in Lowell, Massachusetts, 1826-1860 (New York, 1979); and Jonathan Prude, The Coming of Indiustrial Order: Town and Factory Life in Rural Mfassachusetts, 1810-1860 (Cambridgc, Mass., 1983). 22 Historical Statistics, Part 1, pp. 24-37.

2 Paul A. Groves, "The Northeast and Regional Integration, 1880-1860", in Robert D. Mitchell and Paul A. Groves (eds.), North America: The Historical Geography of a Changing Continent (Totowa, N.J., 1987), pp. 198-217. 
countryside. The wages of unskilled men continued to be determined by the transfer wage and the seasonal earnings of rural workers; and of unskilled women, by a combination of discrimination and a meager range of economic alternatives. And from these asymmetric labor markets issued a supply of cheap labor, which, in combination with machines and the "protection" of international warfare, launched an industrial revolution in the northeastern quadrant of the new nation. The ramifications were many, not the least of which were the emergence of divisions between, on the one hand, unskilled workers and the skilled workers whom they threatened to displace; and, on the other, between low-paid workers and the entrepreneurs who exploited them in the asymmetric labor markets of a developing economy. ${ }^{24}$

\section{Frontier closure and cconomic involution: the emergence of autonomous urban labor markets}

1840 marks a critical turning point in American history. The frontier, which since 1650 had expanded in long cycles of a half century more or less, suddenly came to close. Expansion henceforth ratcheted from the westward extension of settlement to the involutional pursuit of profits and opportunities eastward of the Great Plains. In the several regions Northeast, South, and Midwest - high rates of return accelerated regional economic specialization, stimulated interregional exchange, and, in the north, initiated a fundamental restructuring of urban labor markets. ${ }^{25}$ The latter embarked on the transition from asymmetric dependence on the rural economy to autonomous, if insular, independence. A half-century hence, urban wages would be determined by supply and demand under variable conditions of market perfection - conditions more nearly competitive for the unskilled and more nearly monopsonistic or oligopsonistic for the skilled. In response, skilled workers resisted market imperfections via "combination" and strike; the unskilled, by contrast, complied with economic forces, reaping thereby the benefits of a more less perfectly competitive market. And thus the wedge was driven even deeper into the ranks of labor.

Space precludes extended discussion of the involutional changes responsible for restructuring urban labor markets. Suffice to say that involution in the half century after 1840 stimulated regional economic

24 On the fragility of skilled-unskilled alliances into the 1820 s, see Cynthia J. Shelton, The Mills of Manayunk: Industrialization and Social Conflict in the Philadelphia Region, 17871837 (Baltimorc, 1986); Lenger, "Beyond Exceptionalism", pp. 9-10; Earle, Geographical Inquiry, pp. 400-445. More durable coalitions emerged in the 1830s (signaling, I suspect, the transition from asymmetric to autonomous labor markets); see Montgomery, "The Working Classes", pp. 21-22.

${ }^{25}$ Carville Earle and Changyong Cao, "Frontier Closure and the Involution of American Socicty, 1840-1890". Joumal of the Early' Republic 13 (1993), pp. 163-180. 
specialization and, after the Civil War, the ascent of a hegemonic core region in the urban-industrial Northeast and Midwest. These core states dominated American manufacturing by 1860 when they accounted for over half the nation's establishments, three-fourths of its employees, and nearly three-fourths of its value added. Industrial advance was predicated, of course, on a legacy of cheap, unskilled labor and deployment in cotton textiles and metalworking. But to these industries were added firms producing boots and shoes and ready-made clothing along with a host of firms which processed the vast flow of agricultural commodities from the Midwest. ${ }^{26}$

Frontier closure and the involution of the American economy had several ramifications for industrial workers in the Northeast and Midwest. The first of these is that the agrarian South by and large dealt itself out of the industrialization process. ${ }^{27}$ The second, and more decisive, is that the North experienced an unprecedented concentration of workers in industrial centers. In New England and the Middle States, city dwellers rose from less than 20 percent of the population in 1830 to nearly 35 percent by 1860 to over 60 percent by 1890 . By the latter date, some thirty cities - twenty-four of which were in the northeastern quadrant of the nation - exceeded populations of 85,000 , ten exceeded 250,000 and three exceeded a million. A half-century earlier, by contrast, only five cities had more than 85,000 people. These advances challenged rurality's hegemony over urban labor markets. By 1880, the agricultural sector of the economy was in retreat. Non-agricultural occupations exceeded agricultural ones in the labor force; and a decade hence, manufacturing's value added surpassed agriculture's. Neither situation would be reversed. ${ }^{28}$

These spatial and sectoral changes in the northern economy swiftly restructured northern labor markets. In a score or more cities, labor markets wrested free from rural hegemony - from dependence on agrarian economy, transfer wages, and asymmetric market structures - and installed in its place a series of increasingly autonomous and segmented labor markets. These segments consisted of: (1) a highly competitive market for unskilled labor reffective of the wide range of employment opportunities for these undifferentiated and interchangeable tasks; and (2) an imperfectly competitive market for skilled labor reflective of monopsony or oligopsony, that is, market dominance by one or at most a few firms (buyers). The first of these privileged marginalist wage determina-

${ }^{26}$ Richard F. Bensel, Yankee Leviathan: The Origins of Central State Authority in America, 1859-1877 (Cambridge, 1990); Albert W. Niemi, Jr., State and Regional Patterns in American Manufacturing, 1860-1900 (Westport, Conn., 1974).

"On the agrarian involution of the Southern economy after 1840, sec Carville Earle, "The Price of Precocity: Technical Choice and Ecological Constraint in the Cotton South, 18401890", Agricultural History 66 (1992), pp. 25-60.

2s Hisforical Statistics, Part 1, pp. 24-37, 134, 139; U.S., Census of Population: 1950, Vol.1: Number of Inhabisants (Washington, 1952), pp. 32-33. 
tion, rising relative wages, reduced exploitation, and worker compliance; the second, submarginalist wage setting, falling relative wages, increased exploitation, and the reciprocal of worker protest. ${ }^{29}$

But these restructurings in labor markets were hardly instantaneous. One reason for the delayed reaction was the patchy advance of autonomous markets. Just a handful of large industrial centers satisfied the thresholds for market autonomy in 1840, and only about two dozen northern cities had qualified a half-century hence. But delay ensued even in these centers, which brings us to a second and more decisive cause. In these cities entrepreneurs vigorously resisted market realities. Unskilled wages remained low ("sticky" is the usual name applied to transitional lags between one market structure and another), and entrepreneurs attempted to keep them there. Workers countered by attempting the break "the cake of custom" and hasten the onset of autonomous labor markets. ${ }^{30}$ Toward that end - albeit for quite different reasons - common laborers and skilled workers momentarily joined forces in a rising tide of worker protest and strategic "combination". But the alliance collapsed in the late 1870 s and 1880 s as the unskilled, having secured entrepreneurial obeisance to perfectly competitive labor markets, swiftly disengaged from the fray, complied with the market's dictates, and claimed the benefits of their "golden age". ${ }^{31}$

These awkward and difficult transitions in urban labor markets were played out in the historical geography of worker protest between 1840 and 1890 . With the rise of autonomous labor markets in the 1840 s and $1850 \mathrm{~s}$ and war-time labor shortages in the 1860 s, workers gained leverage in the workplace. Strikes, which had been sporadic before 1850 , increased rapidly during the boom times of the 1850 s and the early 1860 s. Although protest erupted in various locations, the expansive metropolitan centers (and autonomous labor markets) of Boston, Philadelphia, and New York led the way (Figure 1). The end of the war and the ensuing recession

2 The process of labot-market segmentation has its American origins in the rise of autonomous urban labor markets in the period 1840-1890; after 1890, segmentation involves the qualitatively different process of intemalization of labor markets within the firm. See Edwards, Contested Terrain; Peter Doeringer and Michael Piore, Internal Labor Mtarkets and Manpower Analysis (Lexington, Mass., 1971); and Allen J. Scott, Metropolis: From the Division of Labor io Urban Form (Berkeley, 1988), pp. 27-35.

${ }^{30}$ On lagged responses to labor markets, see E.J. Hobsbawn, "Custom, Wages, and WorkLoad in Nineteenth.Century Industry", in his Labouring Men: Studies in the History of Labour (New York, 1964), pp. 244-270.

${ }^{31}$ It is ironic that the post-1870 advance in unskilled wages, rooted as it was in competitive labor markets, has generally eluded neoclassical economists who dwell instead on unioniza. tion, wage levelling, and the free rider. See, for examples, Lloyd Ulman, The Rise of the National Trade Union (Cambridge, Mass., 1955); Barry Eichengreen, "The Impact of Late Nineteenth-Century Unions on Labor Earnings and Hours: Iowa in 1894", Industrial and Labor Relations Revicw 40 (1987), pp. 501-515; and Paul H. Douglas, Real Wages in the United States, 1890-1926 (Boston, 1930). 


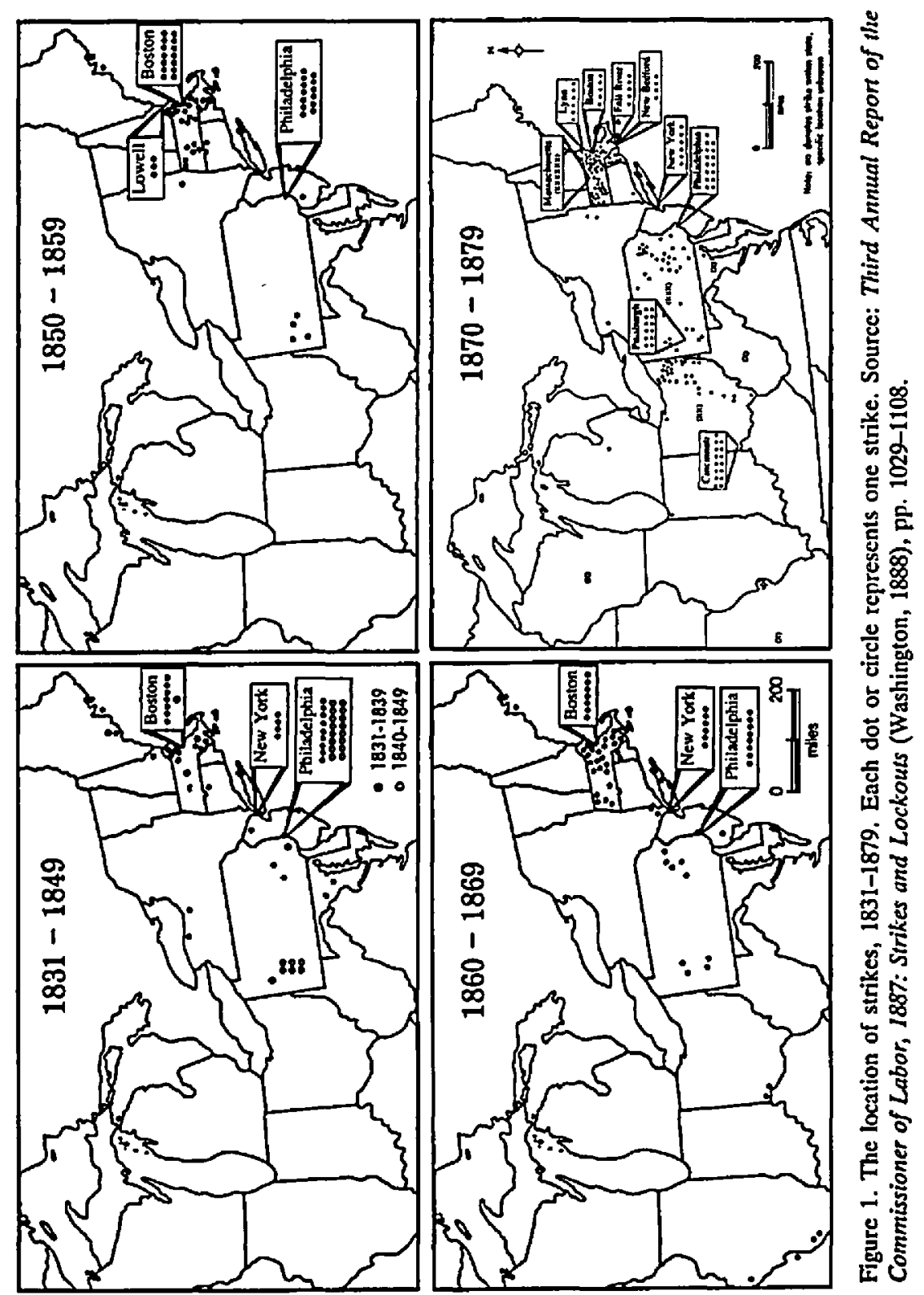


intensified pressures for a new round of wage reductions, but in this case, labor resisted strenuously. Workers simultaneously stepped up the level of protest, founded or expanded some thirty or so labor unions, and attracted some 300,000 members by 1873 . But labor's united front proved ephemeral; and by 1878 a great retreat reduced unions to eight or nine and membership to just $50,000 .^{32}$

The irony of this flurry of worker protest and union activity, 1850-1875, is that it may have been too successful. Workers had jarred industrial entrepreneurs out of habitual wage-setting practices, rudely awakened them to the realities of autonomous urban labor markets, and schooled them in the new principles of wage determination in markets which were more or less competitive. And with the ascent of competitive markets in the 1870 s and 1880 s, unskilled workers withdrew from "combinations" and protest; skilled trade unionists, henceforth, assumed the lead in labor's uprising in the $1880 \mathrm{~s}^{33}$

If the quarter-century or so after 1850 defines a profound transformation in American labor markets and movements - a time when urban entrepreneurs broke "the cake of custom" (the transfer wage) and accepted the realities of autonomous and more or less competitive labor markets and when unskilled workers disengaged from labor's united front - why then did worker protest run at flood-tide in the decade and a half after 1880? The explanation has to do, I think, with a triadic division in labor markets - of segmented labor markets (skilled/unskilled) in industrial cities and of enduring labor-market asymmetry elsewhere - all of which is recorded in the geography of worker protest between 1880 and 1894.

${ }^{32}$ On strikes, see Earle, Geographical Inquiry, pp. 417-423; on unions and Gompers' remarks, Commons, History of Labour, 2, pp. 175-181.

${ }^{33}$ The elimination of seasonal wage differentials and the convergence of skilled and unskilled wages in the 1870 s are suggestive of labor-market transition from rural hegemony to urban autonomy and subsidiary markets more (unskilled) or less (skilled) competitive. Robert Ozanne, Wages in Practice and Theory: AfCormick and Internal Harvester, 1860-1960 (Madison, Wisc., 1968), pp. 3-21; Earle, Geographical Inquiry, pp. 414-416, 440-441. On the advance and retreat of labor's united front between 1860 and 1878, see Norman J. Ware, The Labor Movement in the United Siates, 1860-1895: A Study in Democracy (Gloucester, Mass., 1959), pp. 1-21. One source of the front's fragility was the exotic mixture of ideologies which included, among others, a healthy dose of nineteenth-century market "liberalism" a view not unappealing for unskilled workers in increasingly competitive labor markets. Daniel T. Rogers, The Work Ethic in Industrial America, 1850-1920 (Chicago, 1974), pp. 40-46, 156-157. Martin Sheftner nibbles at the edge of these issues in "Trade Unions and Political Machines: The Organization and Disorganization of the American Working Class in the Late Nineteenth Century", in Ira Katznelson and Aristide R. Zolberg (eds.), Working. Class Formation: Nineteenth-Century Patterns in Western Europe and the United States (Princeton, 1986), pp. 197-276; and Erik Olssen, "The Case of the Socialist Party that Failed, or Further Reflections on an American Dream", Labor Hisiory 29 (1988), pp. 416-449. The quiescence of the unskilled after 1873 has more to do with rising wages and market power than with the "pcasant-like" impotence ascribed to them by Andrea Graziosi, "Common Laborers, Unskilled Workers, 1880-1915", Labor History 22 (1981), pp. 512-544, esp. 519. 525-527. 
A wave of protest broke over the nation in the 1880s, or so it seemed. With strikes increasing exponentially from forty to fifty per year in the 1870 s to over 400 in the early 1880 s and over 900 after 1885 (Figure 2), observers had little time for finer geographical distinctions. They were aware, however, of the obvious - that the overwhelming majority of strikes (some 85 percent) occurred in the northeastern quadrant of the nation and that most were directed toward manufacturing establishments. A closer look at the region between 1881 and 1894 reveals that half of its counties reported at least one strike, that urban counties almost invariably reported strikes, and that six large urban centers - New York, Chicago, Boston, Philadelphia, Pittsburgh, and Baltimore - were responsible for nearly half of the region's 14,455 strikes (Figure 3 ). ${ }^{34}$

The wave of protest thus ran wide and, in places, deep. And it is in these deeper spots where we can discern perhaps the sharpest division in the geography of worker protest - a division between preindustrial and industrial worlds, between smaller communities and larger industrial cities. That division is most evident in the scale reversal of labor power; in the declension of labor power in preindustrial communities and its reconstitution in the larger cities of industrializing American - cities sufficiently large to sustain autonomous labor markets (Figure 4).

But the differences in worker protest in these two worlds extend beyond sheer scale and market autonomy. Consider, for example, the supplemental causes of strikes in the industrial world. In the region's fifty or so largest counties (population of 85,000 persons or more) labor power (the strike rate per 1,000 persons) is largely a function of labor-market autonomy and segmentation. Four market-related variables - population, wage ratios, industrial concentration, and manufacturing wages - account for 65 percent of the variance in strike rates between 1881 and 1894. Population or city size is, of course, a proxy for autonomous labor markets; the convergence of skilled and unskilled wages reflects segmentation into competitive (unskilled) and imperfectly competitive (skilled) markets; rising manufacturing wages are self-explanatory; and industrial concentration implies less imperfection in skilled labor markets and, hence, somewhat more leverage for these workers. These determinants in tandem tell a story of autonomous and segmented labor markets wherein skilled workers, with modest assistance from formal labor organizations or the unskilled, protested against market imperfections and for higher wages and shorter hours. In these protests, neither labor unions nor the Knights of Labor played significant roles. Nor again did factors such as ethnicity or government.

The analysis also underlines the process of market segmentation in urban-industrial America. Skilled workers stood at the forefront of protest and resistance. They conducted the overwhelming number of strikes, and

34 This section on Gilded Age worker protest is based on Earle, Geographical Inquiry, pp. 346-377. 


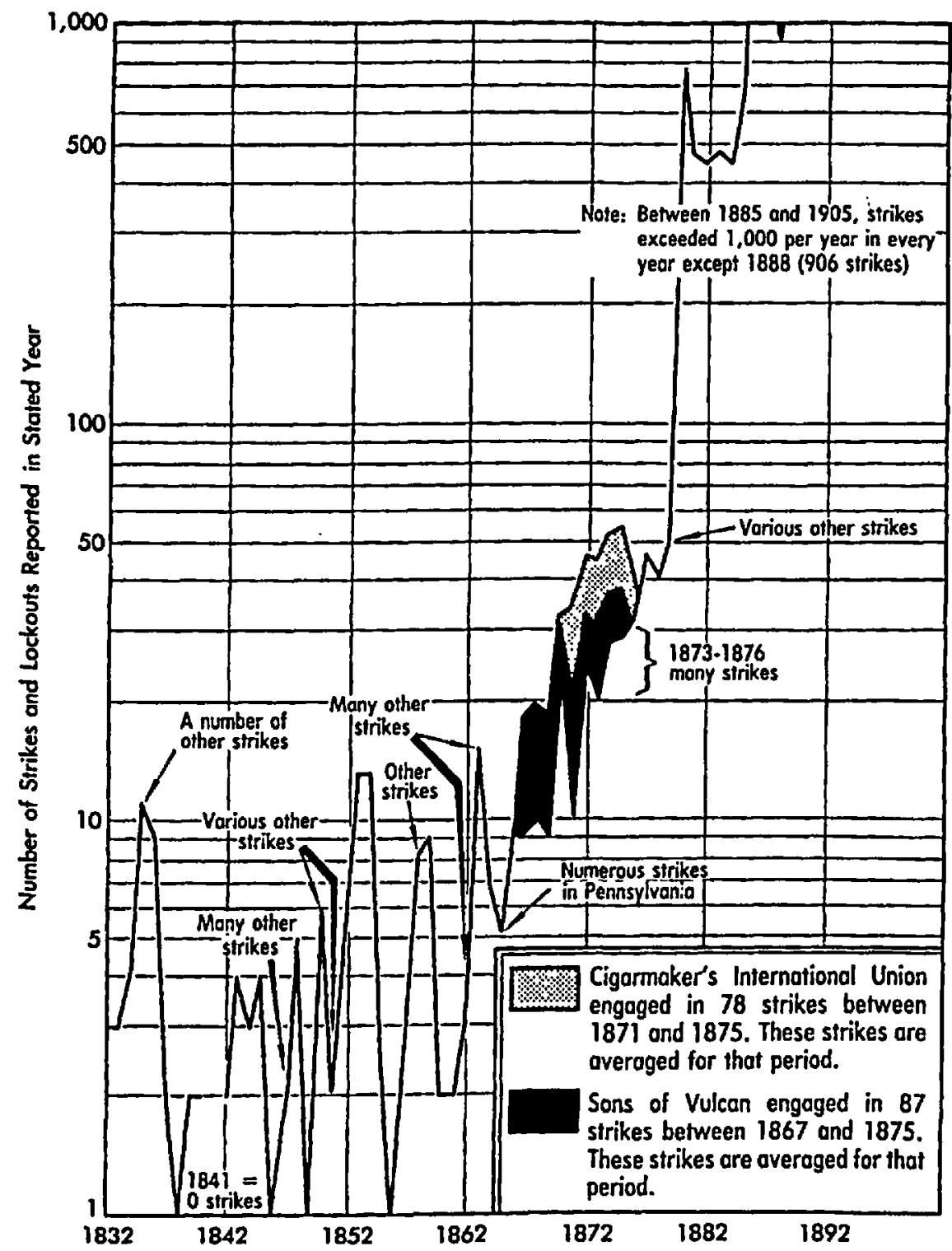

Figure 2. Strikes and lockouts in the United States, 1832-1885. Although the strike count before 1880 is incomplete, the numbers reported here are probably of the right orders of magnitude. Sources: Third Annual Report of the Commissioner of Labor, 1887; Tenth Annual Report of the Commissioner of Labor, 1894; Strikes and Lockouts (2 vols.; Washington, 1896). 


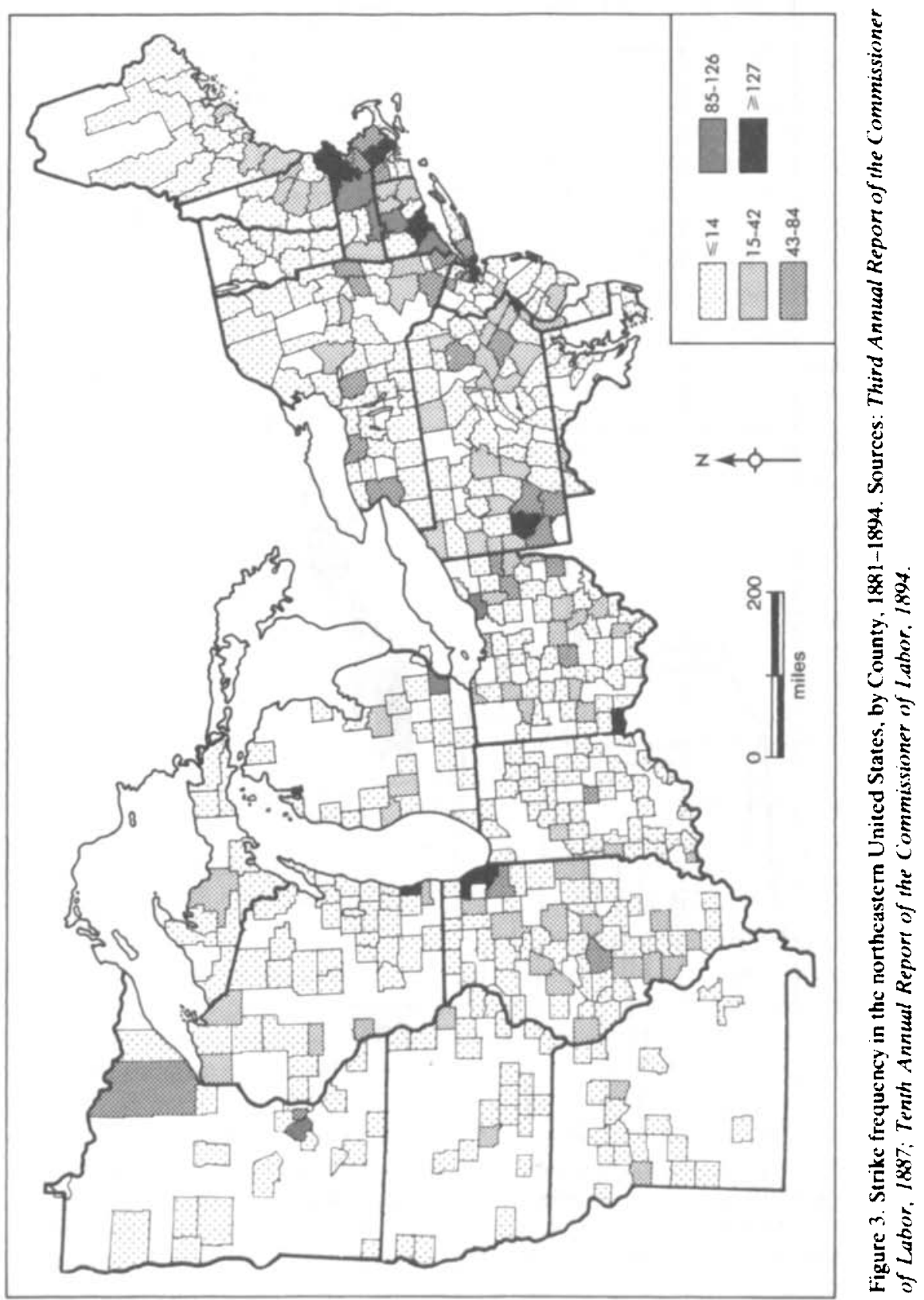




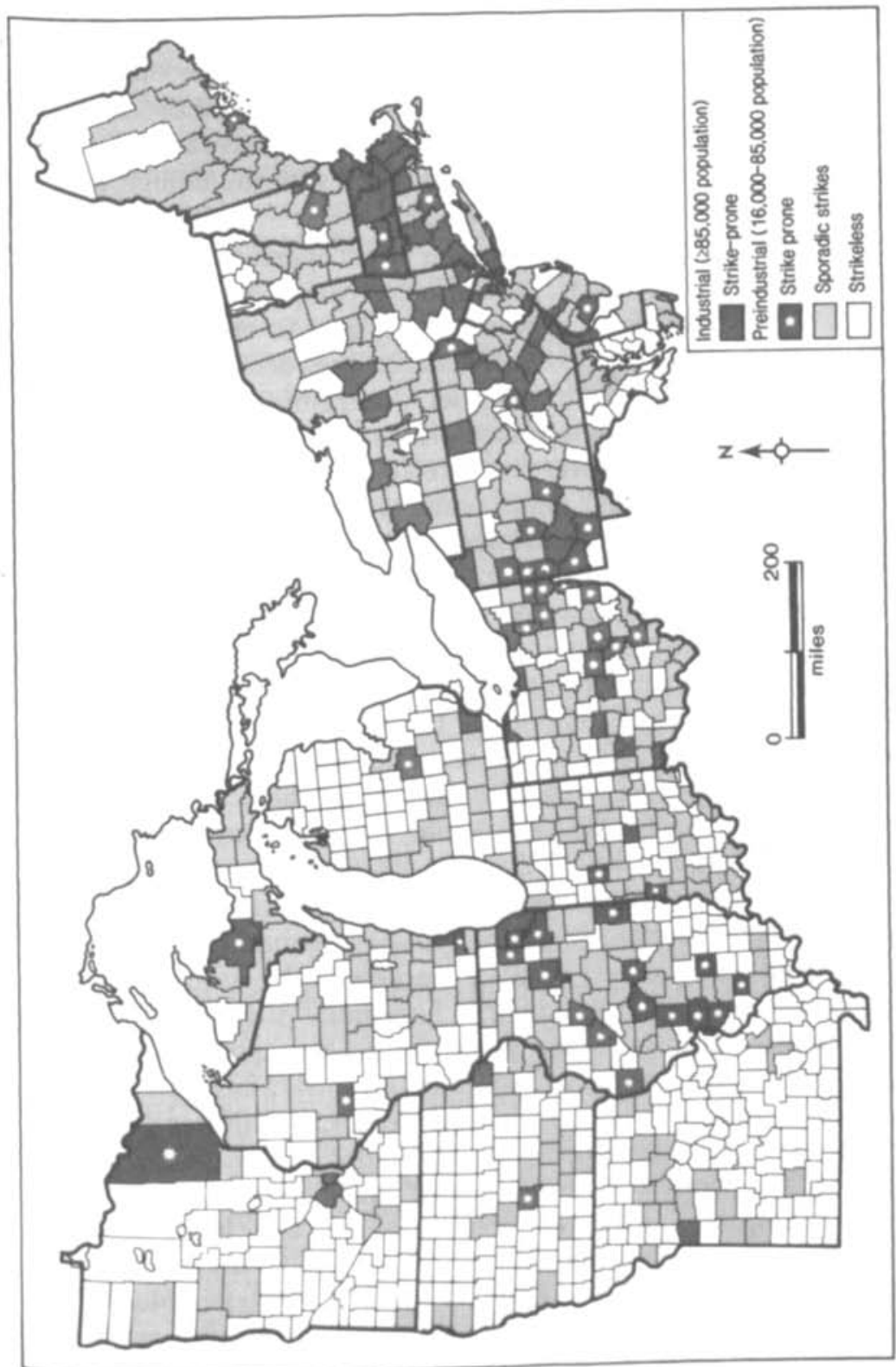

드

F 的害 농

E

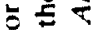

可

है 鞄

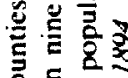
8. ํํํ

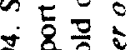
远通

实高点 $\therefore 3$

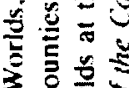
38 可 는 劳要 导离焉 可㤩 븐

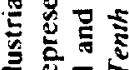

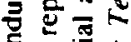
ए. 들 类 家产总 起 乌 E $\checkmark$ 马ं

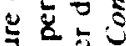
记焉 
they targeted them in cities where particular industries were concentrated - thus reducing the oligopsonistic power of firms - and where unskilled and skilled wages were convergent - thus underlining the ease of exercising labor power in competitive markets and the difficulty of doing so in markets rent by imperfection. Operating in loosely knit "combinations" or in localized trade unions, skilled workers organized protest as a means of "perfecting" imperfections in their labor markets; the unskilled, meanwhile, disengaged from protest and complied with the benign forces of supply and demand in competitive markets.

Beyond these fifty or so large cities stood a world apart. In the preindustrial world of small cities, towns, and mining camps, industrialization steadily chipped away at labor's power. In the sixty or so counties with populations ranging from 16,000 to 85,000 , strike rates declined as communities made the transition from preindustrial to industrial worlds or, more precisely, from asymmetric to autonomous labor markets. Yet within this context of declension, labor power was fueled by organizations such as the Knights of Labor and the Knights" insistence that workers receive larger and more equitable shares of profits. Formal labor organizations accordingly assumed a far larger role in the asymmetric labor markets of preindustrial America than in the autonomous markets in the larger industrial cities.

This geographical analysis of worker protest in the Gilded Age affords a glimpse of the multi-layered relations in labor power, scale, and labormarket transitions. On the surface, we see a cleavage between the two worlds of American labor, a cleavage delineated by the scale reversal of labor power in the course of industrialization. The power of preindustrial labor declines to its nadir in cities of 75,000 to 100,000 persons, after which it is reconstituted in the larger industrial centers of the northern United States. These surfacial expressions of labor power are underlain, however, by a more profound restructuring of labor markets in the course of industrialization. At this level, the preindustrial hegemony of rural labor markets and the agrarian transfer wage gives way to the autonomous (and variously competitive, oligopsonistic, and monopsonistic) markets of metropolitan America. The labor market, in other words, constitutes the intervening variable between industrialization and labor power. All of which is underlined by the market determinants of metropolitan labor power (i.e., scale, wage ratios, industrial concentration, and manufacturing wages). Metropolitan labor is reempowered, as it were, by the ineluctables of scalar shift, the concomitant ascent of autonomous and segmented labor markets, and labor's strategic responses - of compliance with marginalist wage determination in competitive unskilled labor markets and resistance to wages less than marginal product in the imperfect markets for skilled craftsmen. ${ }^{35}$

3s Gutman's thesis of the declension of labor power is inverted in the large cities of industrializing America, Gutman, "The Workers' Search for Power", pp. 38-68. The simultaneous 
The dynamics of labor-market transition thus offers a series of insights on the geographical foundations of worker protest and the deepening schisms within the ranks of labor in the Gilded Age. They also resolve one of labor history's great paradoxes - namely that the least powerful and least educated American workers made the greatest advances in the Gilded Age and that these advances into unskilled labor's "golden age" were accomplished, even more paradoxically, with a modicum of protest and "combination".

The unusual economic success of unskilled workers in the half-century between 1870 and 1920 has been often noted, though less often explained. Much of their success can be traced to the restructuring of labor markets. Had the unskilled continued to earn the transfer wage prevailing in asymmetric labor markets, their wages in 1890 would have hovered around a dollar a day instead of the $\$ 1.45$ which they in fact earned..$^{36}$ This dividend of over 40 percent and the curiously privileged status of unskilled workers has perplexed many scholars, including the author of a pioneering study of workers and wages in the McCormick Reaper Company of Chicago. In the company's round of wage reductions after 1886, Robert Ozanne observes that "common labor" [ . . . ] was exempted completely from the cuts of 1886-1896". Ozanne attributes this situation to benevolence rather than labor markets. "Common labor," he notes:

received favored treatment in 1886 because of the lessons President McCormick had learned in the strikes of 1885 and 1886. Much of the public's antagonism to the company in the 1885 strike, he believed, came from bis across-the-board wage cut of December, 1884, which aroused public sympathy for the low-paid workmen. In the negotiations preceding the strike of 1886 he had raised common labor rates handsomely. When the 1893-1898 recession began, the McCormick Company, to avoid a repetition of the 1885 debacle, cut only the skilled workers and those on piece rates. ${ }^{37}$

Perhaps McCormick's preferential treatment of the unskilled represents an irrational "corporate departure from economic motivation', but the benevolence alleged by Ozanne is just as easily interpreted as calculative rationality. McCormick had sound economic reasons for his actions if we acknowledge the emergence in Chicago of a competitive unskilled labor market. That market provided a wide variety of jobs in hundreds of firms engaged in everything from commodity handling to manufacturing and construction. Firms which failed to pay the market rate in this competitive market swiftly experienced labor flight to neighboring firms. From this vantage point, McCormick's irrational benevolence dissolves into a

ascension of marginalist economics and autonomous, if variably competitive, labor markets seems not altogether fortuitous. Daniel Bell, "Models and Reality in Economic Discourse", in Daniel Bell and Irving Kristol (eds.), The Crisis in Economic Theory (New York, 1981), pp. 46-80, esp. 47-52.

${ }_{36}$ Douglas, Real Wages in the United States, pp. 174-184.

3 Ozanne, Wages in Theory and Practice, pp. 26-33, esp. 32. 
rational response to competitive labor markets characterized by many buyers and sellers, ease of mobility, and efficient communication of job opportunities. Note, moreover, that McCormick's benevolence stopped short in negotiations with skilled workers upon whom he imposed repeated wage reductions - responses one would expect from a rational actor acutely aware of the oligopsonistic market for skilled labor in the 1880s and $1890 \mathrm{s.}^{38}$

If the realities of labor-market segmentation eluded McCormick until the "debacle of 1885', they also confused skilled trade unionists who, in that very year, set about the task of healing the divisions in the ranks of American labor. Under the banner of the Federation of Organized Trades and Labor Unions, trade unionists formulated plans for a general strike on 1 May 1886 and issued a call for a united front for the eight-hour day. In short order, they would learn a great deal about: (1) the peculiar geography of their parochial constituency and (2) following the eruption of violence in Chicago's Haymarket Square on the evening of 4 May, the spatial insularity of American sociogeography. A rehearsal of these events brings us up to speed on a strike which constituted labor's last great chance for uniting the American working class. ${ }^{39}$

FOTLU strategists sought a united front on 1 May, and toward that end they made several overtures to Terrence Powderly and the Knights of Labor. When the Knights reneged, FOTLU decided to proceed alone. On 1 May, some 100,000 workers responded with strike actions of varying size, length, and effect. As the largest strike in American history to that date, organizers were pleased, but it was the spatial lessons of the strike which proved most instructive to them. The first of these indelibly defined the trade unionists" constituency. Most of their support came from large industrial cities and skilled workers therein. Meanwhile, unskilled workers in these cities as well as virtually all workers in preindustrial America remained on the sidelines. These defections notwithstanding, the general strike on Saturday, 1 May mobilized over 100,000 workers in some 200 separate strike actions conducted in over thirty communities. Even after sympathy strikers returned to work on Monday, some 76,000 remained off the job.

The violence on Tuesday evening changed everything, however. Attention, public and historiographic, shifted abruptly from the strike to the independent events of Haymarket and the ensuing trial of anarchists and radicals. In these weeks and months, trade unions learned a second spatial lesson about the remarkable insularity of American sociogeography. Much to their surprise, perhaps, the general strike did not collapse after Hay-

38 On oligopsonistic conditions in Chicago's farm implements industry, see Ozanne, Wages in Theory and Practice, p. 32. On the adoption of McCormick's wage strategies in other industries, ibid., pp. 26-33.

${ }^{3 *}$ For more details and sources of the general strike, see Earle, Geographical Inquiry, pp. 378-399. 


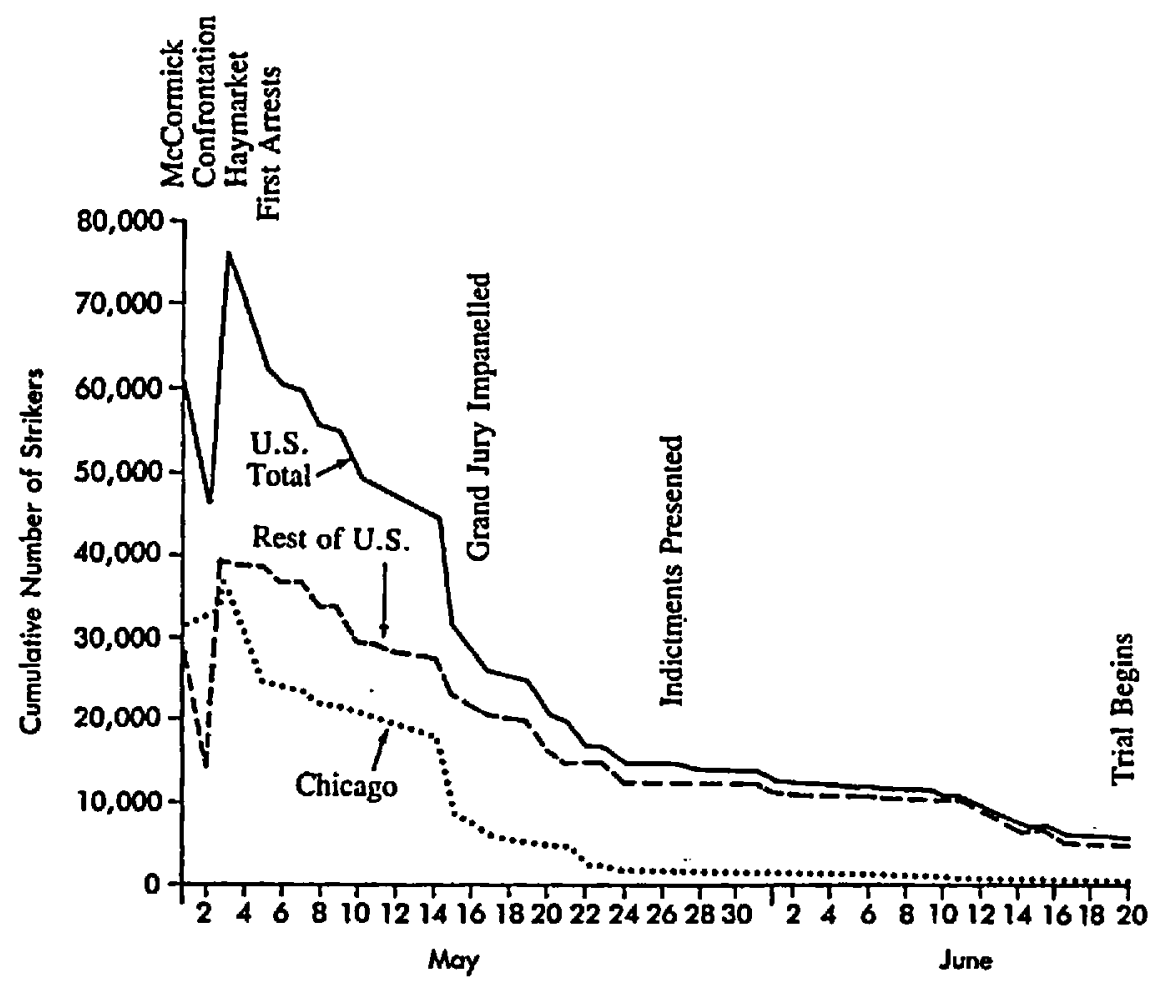

Figure 5. The trajectory of the general strike, 1 May-20 June, 1886. The daily totals of general strikers involve subtraction of general strikers who had concluded their strike from the total number of general strikers who began their protest between 1 May and 3 May, 1886. Source: Third Annual Report of the Commissioner of Labor, 1887.

market. To be sure, these events crippled the strike in Chicago, the locus of violence, where by 11 May strike actions and participants had fallen by 60 and 77 percent, respectively. Elsewhere, however, the rate of dissipation was considerably less - some 40 percent of strike actions and 42 percent of strikers (Figure 5).

These crude spatial divisions are embroidered into a more complex series of ellipses in the accompanying map of the general strike's duration (Figure 6). At the center of the series is Chicago, where the average strike lasted just over two weeks. Just beyond is an inner ellipse arching from Detroit to Pittsburgh to Cincinnati and Minneapolis, where the typical strike lasted two to three weeks; and last is an outer ellipse, where workers stayed off the job for three weeks or more. For trade unions, this elliptical geography taught a straightforward spatial lesson: the impact of violence (or of any other injurious action) on the labor movement diminished rapidly with distance from the center of that action. This lesson - that the United States in the Gilded Age was an insular and distended society in which impulses from one place were weakly transmitted to others - had 


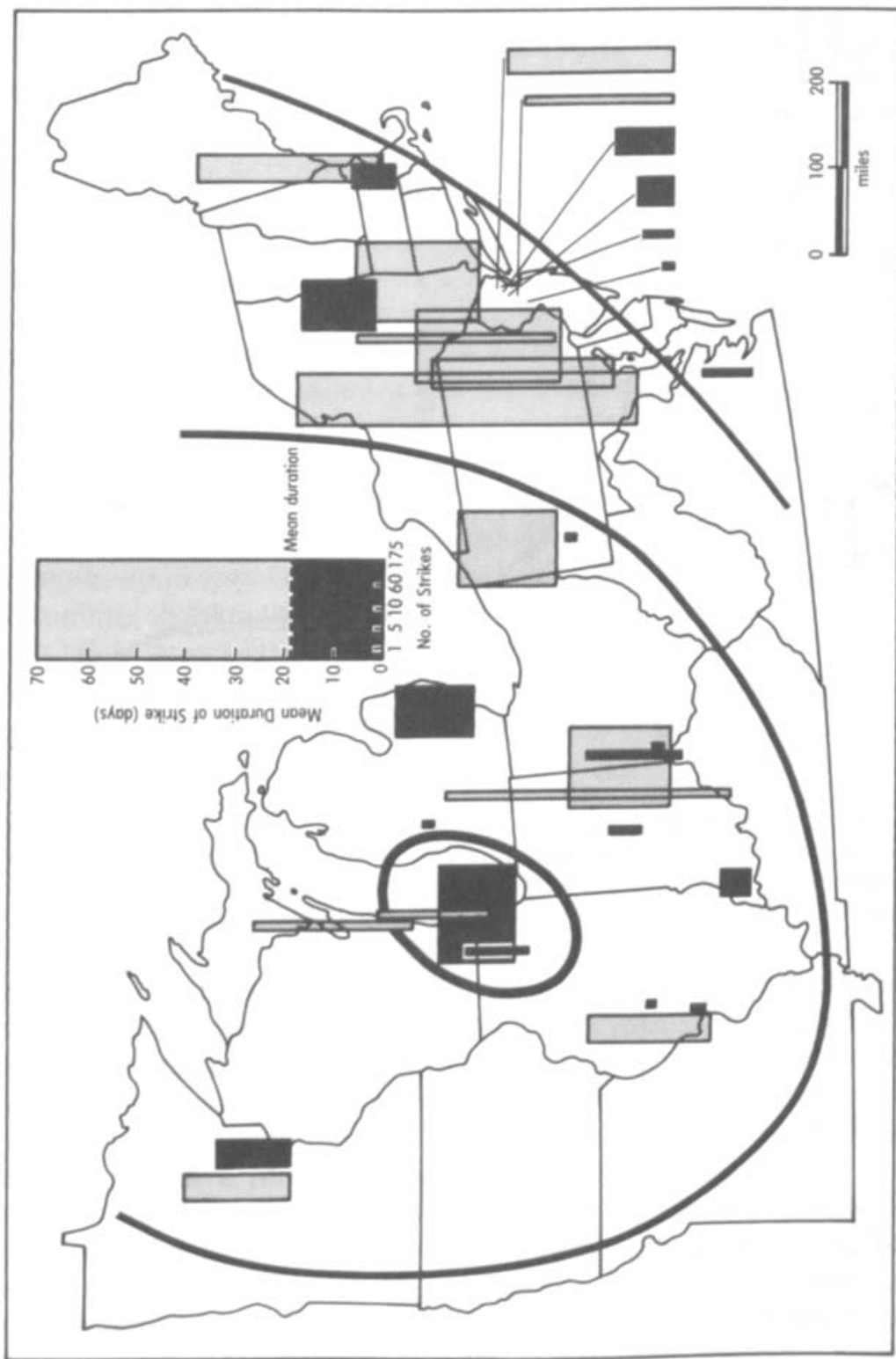

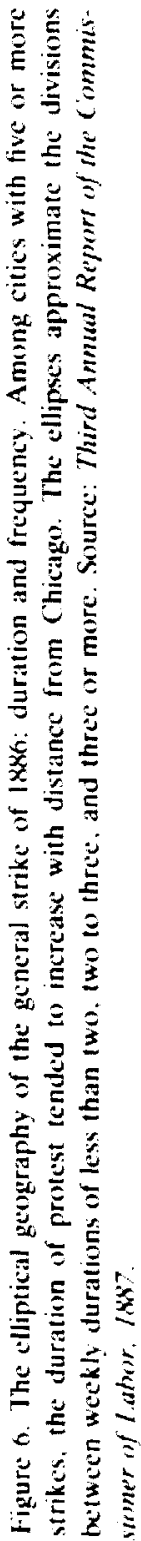


been hammered home to trade unionists long before the historian Robert Weibe made the point. ${ }^{40}$ In such a society, Americans had no reason to believe that Haymarket violence constituted a systemic problem. What happened in Chicago was Chicago's problem, not the nation's at large.

Trade unionists swiftly translated these spatial lessons into policy. In the months ahead, they focused their energies on loyal constituencies in northern urban-industrial centers and on a decentralized mode or organization appropriate to a distended, insular, and weakly articulated sociospatial system. Within the year, trade unionists met in Columbus, Ohio, founded the American Federation of Labor, and embarked on a strategy of "pure and simple" trade unionism. Few now recall that just eight months earlier, these same trade unionists had pursued an alliance of all workers, skilled and unskilled, in large cities and small. At that moment, and despite the deepening structural divisions occasioned by labor markets, wages, and political interests, labor had a unique opportunity for joining ranks, for subordinating interests to solidarity. Failure to do so ensured that the various factions of the labor movement would go their own way. Trade unions, henceforth, decamped in the cities of industrial America and left the rest to the Knights of Labor and their socialist successors in the small towns of preindustrial America.

But industrial America was contested terrain and trade unionists knew that their adversaries had not been idle. McCormick and few industrialists had also learned a great deal about the geography of strikes and labor markets during the 1880 s, and putting their erudition into practice, they ushered in unskilled labor's golden age and skilled labor's time of trial.

Preindustrial and industrial worlds: radical labor politics, scientific management, and the imperfecting of labor markets

The founding of the AFL marked a critical turning point in the history of American labor. Visions of a unified working class henceforth gave way to a triadic division in labor's ranks, a division between skilled and unskilled in industrial America and between them and the workers of preindustrial America. In the half-century that followed, these divisions were accentuated. Skilled trade unionists rapidly expanded their ranks in large cities where they contested the wages and working conditions imposed by imperfect labor markets. Unskilled workers in these industrial centers meanwhile eschewed unionization in favor of compliance with competitive markets. They continued to enjoy the market's benefits until the turn of the century when these were undermined (imperfected) by industry's adoption of Scientific Management practices. And lastly, workers in preindustrial America, bereft of unions or competitive markets, turned toward the radicalism of socialist politics. In summarizing the his-

${ }^{\infty}$ Robert H. Weibe, The Search for Order, 1877-1920 (New York, 1967), pp. 11-43. 
toriographies of these several labor movements, keep in mind that my intent is less a rehearsal of their literatures than a revision in our angle of vision on their geographies and the role of labor markets therein.

Perhaps the best-known of these labor movements is the storied rise and fall of socialism between 1890 and 1920 . What has not been so fully appreciated in these recountings, however, is socialism's intimate association with preindustrial America and the antecedent radicalism of the Knights of Labor. Although the Knights eschewed a political agenda, their radical commitment to organizing all workers within a community had widespread appeal. Founded in 1869, the Knights" membership expanded exponentially and peaked at 700,000 in 1886 . While the Knights operated in the full range of Gilded Age communities, their power seems to have been concentrated primarily in preindustrial America - in cities and towns of less than 85,000. Conversely, they were impotent in big cities and that fact, in tandem with a series of strategic blunders in the mid-1880s rejecting FOTLU's call for a general strike, refusal to condemn the sentences of Haymarket radicals and anarchists, and the loss of several key strikes - contributed to a devolution equally exponential. ${ }^{41}$

The collapse of the Knights by 1890 created a vacuum filled by socialist party politics in the ensuing two decades. Although the urbanbased Socialist Labor Party made little headway in preindustrial America, it nonetheless paved the way for the more inclusive politics of the Socialist Party of America founded in 1901. That party's perennial presidential candidate, Eugene Debs - a resident of the preindustrial Terre Haute, Indiana - scored a number of successes. Debs garnered six percent of the presidential vote in 1912; more significantly, socialist candidates won election to over 1,200 offices and seventy-nine mayorships - virtually of all of which were in the smaller cities and towns of preindustrial America. ${ }^{42}$

The geography of these socialist victories underscores the divisions in the ranks of American labor. Few of them occurred in the large cities of industrial America. Socialist candidates did best in communities in transition between preindustrial and industrial worlds, that is in cities of 50,000 to 100,000 , and between asymmetric and autonomous labor markets. In these places, socialists attempted to get out the vote by uniting all workers in industrial unions. An analysis of Debs' 1912 presidential vote in New York state reveals the extent of their successes. In these transitional communities, proxies for industrial unionism account for 90 percent of the variance in the Debs' vote. When larger industrial cities are incorporated

4s Ware, The Labor Movement in the United States; Jonathan E. Garloch, "A Structural Analysis of the Knights of Labor: A Prolegomenon to the History of the Producing Classcs" (Ph.D. diss., Univ. of Rochester, 1974); Earle, Geographical Inquiry, pp. 428-432.

"2 Ibid., pp. 432-445; James Weinstein. The Decline of Socialism in America, 1912-1925 (New York, 1967). 
into the analysis, however, the level of explanation drops to just 56 percent. ${ }^{43}$

Socialist politics thus flourished among cities in transition from one world to another. They failed utterly, however, in industrial America where trade unionists had consolidated their power in the quarter-century after Haymarket and where unskilled workers enjoyed the protection of competitive labor markets. Radical labor politics thus experienced a brief but useful life in those cities on the hinge between past and future. In this ephemeral stage in the advance of industrialism, defections from socialist ranks were, perhaps, inevitable as the forces of industrialization swept over these cities. To be sure, government repression exacerbated socialism's devolution, but one suspects that these measures were redundant and thus all the more unsavory. ${ }^{4}$

The second and third labor movements of the Progressive Era evolved independently of socialism in the industrial worlds of metropolitan America. Labor markets there had achieved autonomy in the preceding halfcentury of economic involution. Autonomy was accompanied by segmentation into more or less competitive markets for the unskilled and the skilled, respectively, and wages behaved accordingly. By the 1890s, unskilled wages tended to rise as firms competed fiercely for common labor; skilled wages, meanwhile, advanced more slowly and gains were contingent on the efficacy of trade-unionist strategies of combination and protest. And, judging from an analysis of industries in 1890, the results were mixed. Unions yielded positive earnings premia for skilled workers in pig and bar iron, steel, and glass; modest premia in cotton and wool; and negative premia in coal and coke. And given the geography of these industries, unions seem to have been more effective in the Midwest than in the Northeast. Equally significant, unions exerted spillover effects for less skilled, non-union workers. Unskilled and semiskilled workers earned sizable premia in bar iron, steel, wool, and glass. Indeed, semiskilled workers in these industries earned higher premia than the skilled or unskilled. ${ }^{45}$

Yet even as less skilled workers enjoyed the dual benefits of competitive markets and the free rider, their "golden age" was coming to an end.

43 Sari Bennett, "Continuity and Change in the Geography of American Socialism, 19001912". Social Science History 7 (1983), pp. 267-288.

4 Weinstein, The Decline of Socialism; Gabriel Kolko, "The Decline of Radicalism in the Twentieth Century", in James Weinstein and David W. Eakins (eds.), For a New America: Essajs in Histony and Politics from Studies on the Left, 1959-1967 (New York, 1970), pp. 197-220.

«s Patricia Dillon and Ira Gang, "Earnings Effects of Labor Organizations in 1890", Industrial and Labor Relations Review 40 (1987), pp. 516-527; Eichengreen, "The Impact of Late Nineteenth-Century Unions", pp. 501-515. These essays suggest that wage leveling across classes of skill is indicative of union impact on unskilled free-riders, but leveling could just as easily have resulted from competitive markets for unskilled labor. 
Two factors contributed to the post-1900 deterioration in their bargaining power. On the supply side, the market for unskilled and semiskilled labor was occasionally glutted by the vast number of immigrants arriving in the United States. On the demand side, and more critically, the market for their labor was redefined by revolutionary changes in industrial management and the production process. Scientific Management, as it was known, consisted of an array of corporate strategies and concerns - time-andmotion studies, worker efficiency, task simplification, turnover reduction, and worker welfare. Of these, the analytic reduction of industrial production into a series of discrete tasks and correspondingly discrete labor markets may have been the most decisive for unskilled workers. Although the unskilled were still required for hauling and lifting, the new system of hyper-differentiated, firm-specific tasks accented their roles as semiskilled machine tenders. In scientifically managed factories, these operatives expanded as rapidly as the firms' tool and die shops could turn out the templates, jigs, and patterns required for task simplification. ${ }^{46}$

All of this is well known, thanks to David Montgomery and his students; less well understood, however, are the implications of the hyperdifferentiation of tasks on labor markets and their imperfection. The key in this case turns on the spatial instantiation of labor markets, on the fact that the new semiskilled jobs (and their labor markets) were firm-and task-specific. These jobs required training, and hence workers could not easily port their skills from firm to firm. Immobility in turn had two appealing consequences for industrial managers: first, it reduced turnover among semiskilled workers; and second, it imperfected their labor markets which now consisted of few buyers and many sellers. With this new and more elaborate division of labor, scientific managers immobilized semiskilled workers and facilitated their exploitation via monopsonistic and oligopsonistic labor markets. All of which is hardly surprising given management's commitment to differentiation in product markets; was it not logical for managers to extend this venerable principle to labor markets - which they in fact did after $1910 ?^{47}$

The numerous applications of Scientific Management at the turn of the century provide important clues on the diffusion of hyper-differentiated or balkanized labor markets. These geographic reconstructions are hardly straightforward, however, owing to the various versions of Scientific Management propounded and applied by Frederick Taylor and his disciples. C. Bertrand Thompson's 1917 survey may be the most authoritative. He reports adoption of one or another version of these new management

4 Among others, Daniel Nelson, Managers and Workers: Origins of the New Factory System in the United States, 1880-1920 (Madison, Wisc., 1975); Noble, America by Design; and David Montgomery, Workers' Control in America.

"Ton Korver, The Fictitious Commodity: A Study of the U.S. Labor Market, 1880-1940 (Westport, Conn., 1990), pp. 23-42, 107-122, esp. 38. Edwards, Contested Terrain; and Graziosi, "Common Laborers, Unskilled Workers", pp. 1-21. 
principles in fifty-two separate industries and in 169 plants. Of the latter, 117 were located in New England and the Middle Atlantic states. In the case of Taylor's principles, Daniel Nelson notes full application of his system in twenty-nine firms between 1903 and 1918 - and of these, thirteen were in New England, ten in the Middle States, and only two in the Midwest. Scientific Management practices thus seem to have advanced most rapidly in the Northeast and for good reason. There, labor markets were imperfected by the flood of immigration as well as the balkanization of industrial tasks. Unionization, meanwhile, had failed to eliminate these imperfections (recall that unionization of regional industries was associated with lower, even negative, wage premia for all classes of workers). ${ }^{48}$

These East-Coast applications of Scientific Management constituted the first tentative phase in labor-market transition. In the nation as a whole, however, semiskilled workers in manufactures actually declined relative to the number of unskilled workers in the first two decades of the century. Their twofold advantage in the manufacturing workforce of 1900 fell to just 40 percent by 1920 - a shrinkage that was probably attributable to wartime labor scarcity. Thereafter, however, the ranks of the semiskilled expanded rapidly, rising over two-and-a-half-fold by 1940 , as unskilled workers were "upgraded" to machine tenders. In this second, post-1920 phase, the balkanization of labor markets proceeded most rapidly in a series of new and more widely distributed industries - electrical machinery, petroleum refining, canning, drugs and medicines, rubber, and automobiles - as well as a few familiar ones - sawmills, furniture, knitting mills, apparel, yarn-thread-fabric, pulp and paper, and printing and publishing. Labor-market instantiation had spread from the east to the American manufacturing belt as a whole. ${ }^{49}$

The two-step diffusion of Scientific Management practices can be regarded, in retrospect, as industry's response to growth - to the rapid expansion of manufacturing after 1900 and to a concomitant shrinkage in the supply of semiskilled operatives. Taylor's system provided a measure of order and discipline in unruly factories where unskilled workers (often immigrants) had been thrown into the breech, and where they came and went in rapid succession. By reducing tasks to their simplest terms and by training unskilled workers to do them, Taylor's system at once combated turnover, converted common laborers into semiskilled machine tenders, deskilled artisans and craftsmen, and, above all, balkanized the division of labor and labor markets. In place of generalized markets for skilled and unskilled labor, the new system of management created a myriad of

4 C. Bertrand Thompson. The Theory and Practice of Scientific Management (Boston, 1917), pp. 37-40; Nelson, Managers and Workers, pp. 68-78.

"Historical Statistics, Part 1, pp. 143-145; Graziosi, "Common Laborers, Unskilled Workers", pp. 533-534. 
small labor markets each associated with a routinized and firm-specific task. $^{\text {so }}$ And incidental to the progressive search for order, competitive labor markets were eliminated, wages were leveled, and routinized workers were alienated from their products. All of this came to pass in the 1920s and 1930s, a half-century or so after McCormick's wage policies had heralded the unskilled workers' "golden age". Managers heralded, by contrast, a new age of labor relations. Having discerned the complexities of industrial processes, they installed a commensurately complex hierarchy of routine tasks for semiskilled machine tenders and operatives in particular firms.

In this fashion, Scientific Managers undermined the golden age of unskilled labor. The competitive markets and marginalist pricing which had prevailed in unskilled labor markets since 1870 were largely eliminated after 1920 by a splintered division of semiskilled labor and attendant market imperfections. Semiskilled workers, of course, resisted their maneuvers and closed ranks in an ironic struggle for competitive markets and a just share of their marginal products. That they came up short has been repeatedly confirmed. By the $1950 \mathrm{~s}$ - when balkanization of the manufacturing workforce was largely a fait accompli - laborers and service workers were paid only half of their marginal revenue products; craftsmen and operatives even less. Exploitation arising from labor-market imperfections, in other words, hit hardest at the skilled and the semiskilled - a pattern which traces its origins to the half-century between 1880 and 1930 , and its climax to the 1950s. ${ }^{51}$ Unskilled workers fared better owing to the presence of more competitive markets; but the key point is that there were far fewer of them (16 percent) in manufacturing jobs in 1950 as compared either to their contemporaries in skilled ( 34.4 percent) and semiskilled jobs ( 50.0 percent) or to their unskilled predecessors (nearly a third) before 1930.52

The geography of hyper-differentiation in industrial labor markets after 1900 began in the northeastern states (1900-1920) and spread slowly thereafter into the industries of the Midwest. The imperfections which accompanied these splintered divisions of labor invited a new round of industrial conflict as skilled and semiskilled workers sought their marginal products. The spatial patterning of worker protest reflects this diffusion process (Figure 7). Between 1890 and 1920, strike rates were highest in New England and the Middle States where the principles of Scientific Management and the new division of labor were most refined. A half-century hence, as these methods and markets diffused throughout the American manufactur-

${ }^{30}$ Noble, America by Design, esp. p. 300; Korver, The Fictitious Commodity, p. 74.

s1 On manufacturing wages and market imperfections in the 1950s, see Peter Gottschalk, "A Comparison of Marginal Productivity and Earnings by Occupation". Industrial and Labor Relations Review 31 (1978), pp. 368-378.

${ }^{2}$ Historical Statistics, Part 1, pp. 143-145. 

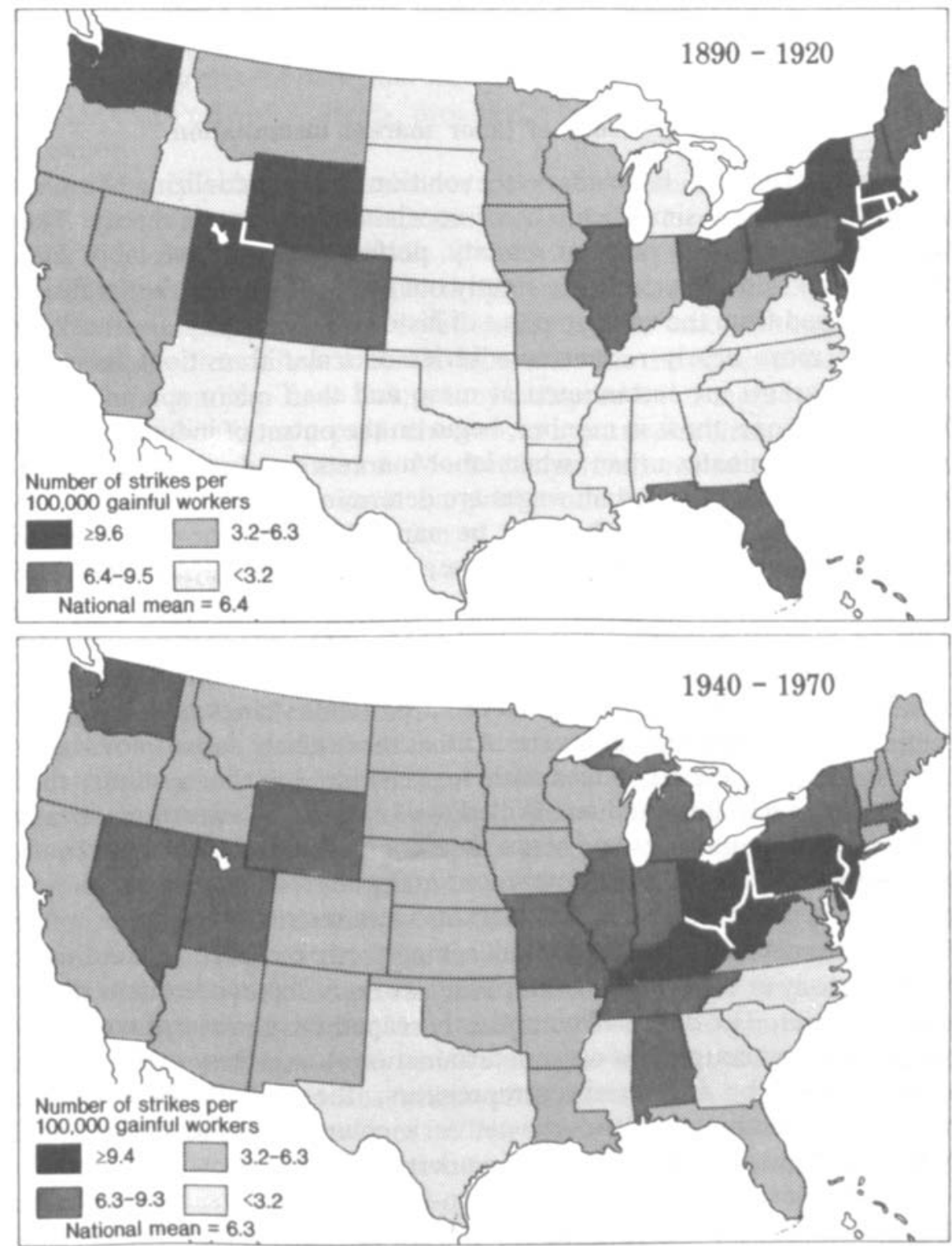

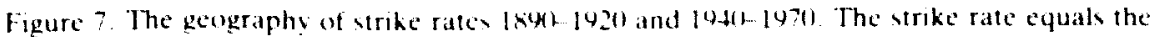
number of strikes in the perionl divided by the labor force at the periods end. Sonure: Earle and Bennett. "The Ceography of Worker Proted" pp. 15-22.

ing belt. similarly high rates of worker protest spread into the Midwest and spilled southward into Kentucky. Tennessec, and Alabamat. Semiskilled workers. confronted by market imperfections, recapitulated the response of skilled workers in the $1880 \mathrm{k}$. Through "combination" and protest, they 
sought little more than the wages to which, in accordance with marginalist economic theory, they were entitled..$^{53}$

\section{Toward a theory of labor market instantiation}

The complexities of labor-market evolution in industrializing America mock the doctrinal simplifications of neoclassical economic theory. That theory's presumptions of labor scarcity, perfectly competitive labor markets, and marginalist pricing are simply out of touch with market realities. When judged from the vantage point of historical geography, the market's evolution more nearly resembles a series of scalar transitions in which abstract markets are instantiated at meso and then micro spatial scales. These transitions, three in number, begin on the outset of industrialization when rural dominates urban, when labor markets are dual and asymmetric, and when unskilled urban wages are determined, in large measure, by the alternative wages which could be earned in more or less seasonal agrarian regimes. In the American case, or more precisely in the northeastern states, cheap unskilled labor and machines provided the foundations for industrial advance and schism in the ranks of labor..$^{34}$

Once underway, industrialization and urbanization redefined the extent of labor markets by narrowing them to particular cities and industrial centers. Space collapsed, as it were. And as these newly autonomous labor markets severed their linkages with region-wide agrarian systems, they also fissioned into unskilled and skilled markets which varied dramatically in their spatial boundaries and hence their competitiveness. Unskilled markets functioned citywide; they embraced many buyers and sellers and were more nearly competitive. Skilled markets were restricted to one or a few firms in the city. They operated under imperfectly competitive conditions of monopsony or oligopsony. In response, workers deployed equally divergent strategies. The unskilled compliantly reaped the benefits of competitive markets and marginalist wage determination - once these realities were acknowledged by industrial entrepreneurs; the skilled, by contrast, resorted to combination and protest as a counterpoise to the unusual power of a few firms in these labor markets.

Beyond these two dozen or so urban-industrial centers, however, the structure of traditional labor markets endured. In response to the dual

53 Carville Earle and Sari Bennett, "The Geography of Worker Protest in the United States", Journal of Geography 82 (1983), pp. 15-21. On the intraurban geography of segmented labor markets, see Allen J. Scott, Metropolis.

34 The scalar instantiation of labor markets might also be regarded as a version of transactional behavior in which firms internalize transactions until their marginal costs equal the transaction costs on the open market - or, in unvarnished prose, until the savings from labor exploitation are exhausted. See Ronald Coase, "The Nature of the Firm", Economica 4 (1937), pp. 386-405; Scott, Metropolis, pp. 27-35. Transactional-cost models tell us very little, however, about the historical preconditions for the internalization of transaction costs within firms (after 1900) or within cities (after 1840) - that is, about scalar transition. 
and asymmetric labor markets of preindustrial America, workers there adopted a strategy of inclusivist radicalism. In their attempts to unite the entire working class of particular localities, the Knights of Labor, and later the Socialist Party of America, provided a temporary salve for a world in transition.

As industry achieved dominance over the American economy after 1880 , labor markets entered their third stage. In the large industrial centers in New England and the Middle States, scientific managers further collapsed labor's space. They reduced the complexities of industrial production to its simplest tasks, narrowed each of these tasks to the particular firm, and then enskilled common laborers with the semiskilled capacity for machine tending. In so doing, they collapsed labor-market space from the city as a whole to a particular job in a particular firm, that is, via a process of scalar instantiation. Market imperfections, of course, ensued; workers earned less than their marginal products; and they responded in kind. In the wake of the diffusion of Scientific Management, semiskilled workers dusted off the repertoires of protest which skilled labor had earlier honed to a fine point. Worker protest, accordingly, spread first throughout New England and the Middle States and, after 1940, into the Midwest and the central South.

Labor-market evolution continues, but the evidence suggests that the process of spatial instantiation has reached its limits. In two centuries, the spatial extent of these markets has been progressively, if unevenly, narrowed - from the agrarian region to the autonomous urban market to the particular job in a particular space in a particular firm. What is left? At the moment, industrial relations seems to pose one of three distinct spatial choices: stay in, move from, or obliterate space. Many firms do all three simultaneously. Staying means an in-place search for alternatives to adversarial relations through schemes such as worker participation, horizontal management, shareholding, and the like. Leaving means a search for new sites and new (and usually unorganized) workers at home or abroad. Obliterating means eliminating labor markets altogether by installing "intelligent" machines in their space. None of these alternatives, of course, is particularly attractive for workers in a technically complex, global society.

In any event, from this historical geography of American labor emerges an enduring axiom for workers, and it is this: the wages of labor are limited only by the spatial restraints on the market which - owing to agrarian seasonality and the several imperfections of monopsony, oligopsony, and splintered divisions of labor - are (and have been) more typical than not. 